\title{
Simultaneous Determination of the Composition and Size of Oxide Particles in Solid Materials by Laser Ablation-Inductively Coupled Plasma Mass Spectrometry
}

\author{
Andrey V. Karasev ${ }^{1,2}$ and Ryo Inoue ${ }^{1}$ \\ ${ }^{1}$ Institute of Multidisciplinary Research for Advanced Materials, Tohoku University, Sendai 980-8577, Japan \\ ${ }^{2}$ Department of Materials Science and Engineering, Royal Institute of Technology, 10044 Stockholm, Sweden
}

\begin{abstract}
Laser ablation-inductively coupled plasma mass spectrometry (LA-ICP-MS) has been used for the determination of the composition and size of oxide particles consisting of $\mathrm{SiO}_{2}, \mathrm{MnO}, \mathrm{Al}_{2} \mathrm{O}_{3}, \mathrm{MgO}$ and $\mathrm{CaO}$ on the surface of a glass or metal sample. The composition and size of multicomponent oxide particles such as $\mathrm{MnO}-\mathrm{SiO}_{2}, \mathrm{CaO}-\mathrm{Al}_{2} \mathrm{O}_{3}$ and $\mathrm{CaO}-\mathrm{Al}_{2} \mathrm{O}_{3}-\mathrm{MgO}$ evaluated by LA-ICP-MS are compared with those obtained by chemical analysis and by SEM observation. It is confirmed that LA-ICP-MS method has prospects to be applied for quick and simultaneous measurement of the composition and size of particles on the surface of metals in steelmaking industry. The difference between the particle size determined by LA-ICP-MS and that by SEM ranges from 6 to $13 \%$ on an average in the range of $d_{\mathrm{V}}=7 \sim 40 \mu \mathrm{m}$. [doi:10.2320/matertrans.MRA2008301]
\end{abstract}

(Received August 29, 2008; Accepted November 13, 2008; Published January 25, 2009)

Keywords: laser ablation, inductively coupled plasma, mass spectrometry, oxide particle, inclusion

\section{Introduction}

It is well known that the particles, which present as inclusion in high quality materials such as steels and alloys, influence considerably their mechanical properties. Therefore, the development of a rapid and accurate method for simultaneous determination of composition, size and number of particles is necessary for the quality control of these materials, especially during those continuous productions.

The laser ablation-inductively coupled plasma-atomic emission spectrometry (LA-ICP-AES) and the laser ablation-inductively coupled plasma-mass spectrometry (LAICP-MS) are known as the well-accepted analytical techniques in view of the quick analysis of solid samples with high precision, ${ }^{1-16)}$ which was reported as approximately 5 to $10 \%$ for most of elements. $\left.{ }^{5,11}\right)$ The utilization of these methods has been reported often for direct analysis of total composition of steels, ${ }^{1-5,11,14)}$ ceramics and rocks ${ }^{7,9,10,16)}$ and for determination of element segregation in minerals and rocks. ${ }^{6,8,12,13,15,16)}$ Mochizuki et al., ${ }^{3)}$ Akiyoshi et al. ${ }^{4)}$ and Ishibashi ${ }^{5,11,14)}$ investigated the favorable condition of the laser ablation in detail, and applied LA-ICP-AES to the in-situ analysis of steel matrix in steelmaking plant.

In previous reports, ${ }^{17-19)}$ it was concluded that LA-ICP-MS can be successfully applied to the composition and size determination of oxide particles containing $\mathrm{Al}_{2} \mathrm{O}_{3}, \mathrm{MgO}$ and $\mathrm{CaO}$ in metals and alloys deoxidized with $\mathrm{Al}, \mathrm{Mg}$ and $\mathrm{Ca}$. However, the other elements such as $\mathrm{Si}, \mathrm{Mn}$ and $\mathrm{Ti}$ are used also often in steelmaking processes for deoxidation and alloying. In this study, the results of previous investigations ${ }^{17-19)}$ are summarized, and then supplemented with respect to the application of LA-ICP-MS method to the analysis of composition and size of one component and multicomponent particles consisting of $\mathrm{Al}, \mathrm{Mg}, \mathrm{Ca}, \mathrm{Mn}$ and $\mathrm{Si}$ oxides. For this purpose, the calibration lines for $\mathrm{Si}$ and $\mathrm{Mn}$ have been obtained. The results of particle composition and size measured by using LA-ICP-MS are compared with those by chemical analysis and SEM. An error of particle size measurement by LA-ICP-MS is estimated for particles in the range of $d_{\mathrm{V}}=7 \sim 40 \mu \mathrm{m}$.

\section{Experimental}

\subsection{Instrumentation}

An inductively coupled plasma mass spectrometer (Hewlett-Packard HP-4500) combined with a laser ablation system (CETAC LSX-100) is used. In laser ablation system, the $\mathrm{Nd}$ :YAG laser is operated in Q-switched mode. A sample in a chamber is irradiated by a laser under Ar carrier gas. The laser beam melts the surface of analyzed sample, ablates and forms fine aerosols. The sample aerosols are swept on a stream of Ar carrier gas directly to the ICP and are ionized by plasma. Then, number of ions for each element is determined by mass spectrometry. The CCD camera system with magnification from 20 to 200 make possible to observe the process of melting and ablation of material on a sample surface in chamber of LA-ICP-MS. The basic instrumental conditions and operating parameters are listed in Table 1. Detailed description of the LA-ICP-MS system was given elsewhere. ${ }^{17)}$

\subsection{Standard sample for determination of particle composition}

Mochizuki et al. ${ }^{20)}$ developed a new method in the utilization of aqueous standard solutions to the calibration of alloying element contents in low alloy steels, which was determined by LA-ICP-AES, but solid standard samples such as glasses and metals have been used usually in LA-ICP-AES and LA-ICP-MS. Because the heterogeneity of commercial glass and metal standard samples was observed in our preliminary experiment, standard glass samples were synthesized as follows: The glass samples of $13 \% \mathrm{NiO}-72 \% \mathrm{~B}_{2} \mathrm{O}_{3}-$ $15 \% \mathrm{Li}_{2} \mathrm{O}$ and $60 \% \mathrm{SiO}_{2}-21 \% \mathrm{~B}_{2} \mathrm{O}_{3}-19 \% \mathrm{Li}_{2} \mathrm{O}$ (in mass $\%$ ) with different contents of $\mathrm{M}_{x} \mathrm{O}_{y}(\mathrm{M}=\mathrm{Mn}, \mathrm{Si}, \mathrm{Al}, \mathrm{Mg}, \mathrm{Ca}, \mathrm{Ti}$ and $\mathrm{Fe}$ ), which used for the analysis of particle composition, were prepared as follows: A mixture $(10 \mathrm{~g})$ of pure $\mathrm{B}_{2} \mathrm{O}_{3}$, $\mathrm{Li}_{2} \mathrm{CO}_{3}$ and $\mathrm{NiO}$ or $\mathrm{SiO}_{2}$ powders was melted in a Pt dish at $950^{\circ} \mathrm{C}$ and held for 30 minutes at this temperature. This melt was stirred by a pure iron rod at interval of 10 minutes for homogenization. Then, an appropriate amount of $\mathrm{M}_{x} \mathrm{O}_{y}$ powders was added to the melt, followed by stirring for 10 
Table 1 Instrumental conditions and operating parameters.

\begin{tabular}{|c|c|}
\hline \multicolumn{2}{|c|}{ ICP-MS } \\
\hline RF power/W & 1100 \\
\hline \multicolumn{2}{|l|}{ Ar-gas flow rates $/ \mathrm{L} \cdot \mathrm{min}^{-1}$} \\
\hline plasma & $15.0-16.0$ \\
\hline auxiliary & $1.0-1.1$ \\
\hline carrier & 1.4 \\
\hline Integration time $/ \mathrm{s}$ & 0.1 \\
\hline \multicolumn{2}{|c|}{ Laser Ablation } \\
\hline Type of laser & Nd:YAG \\
\hline Wavelength/nm & 266 (UV light) \\
\hline Laser scan rate $/ \mathrm{mm} \cdot \mathrm{s}^{-1}$ & 0.01 \\
\hline Frequency of the laser shot $/ \mathrm{Hz}$ & 20 \\
\hline Laser energy $/ \mathrm{mJ} \cdot \operatorname{shot}^{-1}$ & $2.0-3.0$ \\
\hline Defocus of laser beam $/ \mathrm{mm}$ & 0 \\
\hline
\end{tabular}

seconds. After cooling, this sample was crushed, melted again and held for 30 minutes at $950^{\circ} \mathrm{C}$. This procedure was repeated 5 times for homogenization. Homogeneity of glass composition for each sample was examined by LA-ICP-MS. These samples are used as the laboratory standards for the quantitative analysis of particle composition.

\subsection{Standard sample for measurement of particle size}

In order to obtain the relationship between the particle size and the $\mathrm{Al}$ intensity peak ${ }^{21)}$ during optical emission spectrometry, the standard sample for the measurement of particle size was prepared by sintering the mixture of classified $\mathrm{Al}_{2} \mathrm{O}_{3}$ particles with pure iron powder using a hot isostatic pressure (HIP) method. In present work, the samples containing synthetic particles on a surface were prepared as follows: Synthetic material of $\mathrm{MnO} \cdot \mathrm{SiO}_{2}$ and $2 \mathrm{MnO} \cdot \mathrm{SiO}_{2}$ were obtained by melting a pressed mixture of appropriate amount of $\mathrm{MnO}$ and $\mathrm{SiO}_{2}$ powders at $1520^{\circ} \mathrm{C}$ for 5 minutes under an Ar atmosphere in a Mo crucible, followed by quenching on a water cooled copper plate. After crushing and sieving, the synthetic particles with the size of 7 to $40 \mu \mathrm{m}$ were pasted with a double-coated carbon adhesive tape on a pure copper holder $(99.999 \% \mathrm{Cu})$.

Synthetic particles such as $\mathrm{CaO} \cdot 2 \mathrm{Al}_{2} \mathrm{O}_{3}\left(\mathrm{CA}_{2}\right), \mathrm{CaO}$. $\mathrm{Al}_{2} \mathrm{O}_{3}(\mathrm{CA}), 12 \mathrm{CaO} \cdot 7 \mathrm{Al}_{2} \mathrm{O}_{3}\left(\mathrm{C}_{12} \mathrm{~A}_{7}\right), 3 \mathrm{CaO} \cdot \mathrm{Al}_{2} \mathrm{O}_{3}\left(\mathrm{C}_{3} \mathrm{~A}\right)$, and $\mathrm{MgO} \cdot \mathrm{Al}_{2} \mathrm{O}_{3}$ (MA) were obtained by sintering a pressed mixture of appropriate amount of $\mathrm{CaCO}_{3}$ or $\mathrm{MgO}$ and $\mathrm{Al}_{2} \mathrm{O}_{3}$ powders at $1300^{\circ} \mathrm{C}$ for $72 \mathrm{~h}$ in a Pt crucible. Particles of $35 \%$ $\mathrm{CaO}-57 \% \mathrm{Al}_{2} \mathrm{O}_{3}-8 \% \mathrm{MgO}(\mathrm{CAM})$ were obtained by melting a mixture of $\mathrm{CaCO}_{3}, \mathrm{Al}_{2} \mathrm{O}_{3}$ and $\mathrm{MgO}$ powders at $1580^{\circ} \mathrm{C}$ for 10 minutes in an induction furnace by using a $\mathrm{MgO}$ crucible, followed by quenching on water cooled copper plate. After crushing and sieving, the particles in the range of $d_{\mathrm{V}}=7 \sim 40 \mu \mathrm{m}$ were placed on one end of a copper cylindrical rod and then pressed on the glass $\left(60 \% \mathrm{SiO}_{2}-21 \%\right.$ $\mathrm{B}_{2} \mathrm{O}_{3}-19 \% \mathrm{Li}_{2} \mathrm{O}$ ), which was previously melted at $950^{\circ} \mathrm{C}$. The photomicrographs of synthetic particles on a surface of glass sample are shown in Fig. 1.

The glass samples with pure $\mathrm{Al}_{2} \mathrm{O}_{3}$ and $\mathrm{MgO}$ particles on a surface were prepared in the same procedure. The standard powders of white fused alumina (JIS Z 8901-No. 3, 4 and 5, $\mathrm{Al}_{2} \mathrm{O}_{3} \geq 99 \%$ ) with the size of $7 \pm 2,13 \pm 3$ and $27 \pm 6 \mu \mathrm{m}$
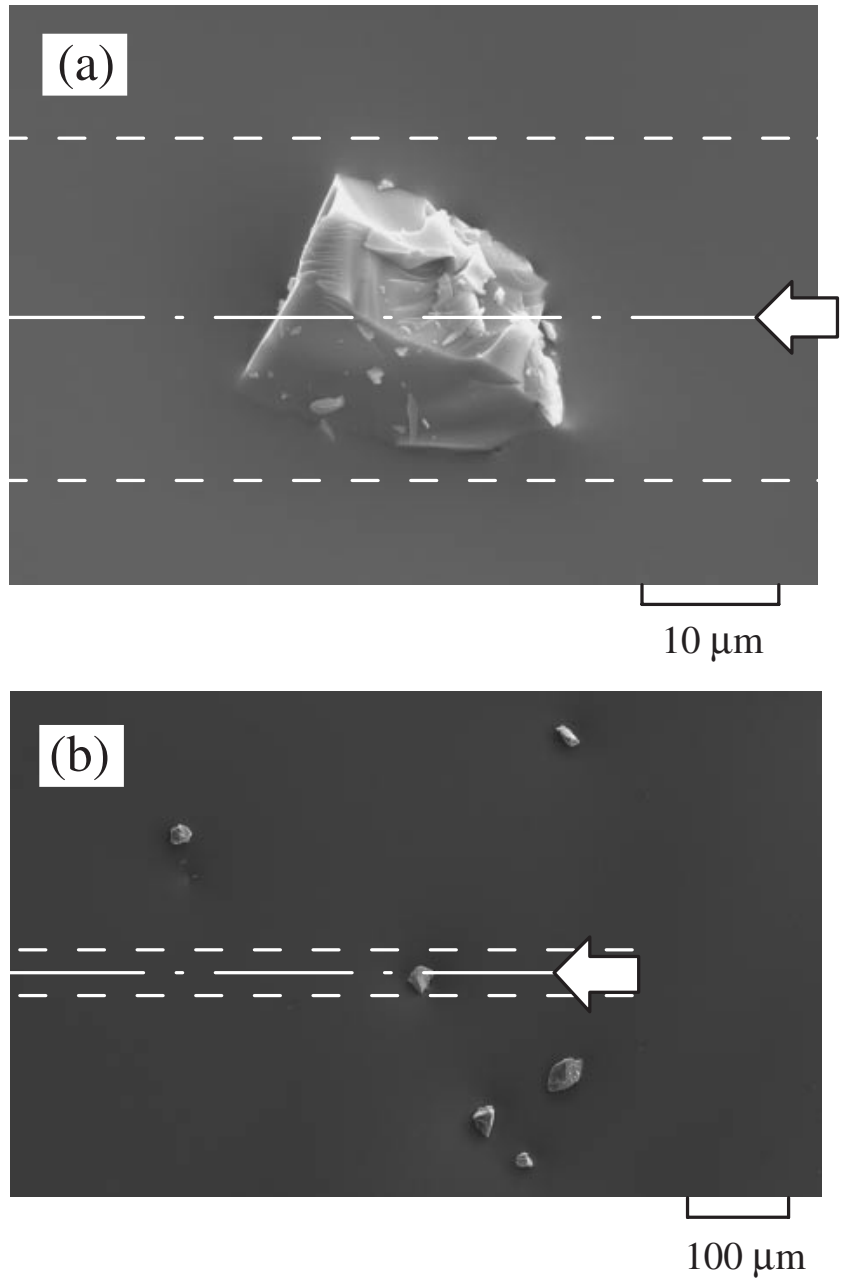

Fig. 1 Synthetic particles on surface of glass sample and position of intended track during laser ablation.

were used as pure $\mathrm{Al}_{2} \mathrm{O}_{3}$ particles. The pure $\mathrm{MgO}$ particles in the size range of 10 to $40 \mu \mathrm{m}$ were obtained by crushing and sieving of high purity $\mathrm{MgO}$ crucible $(\mathrm{MgO} \geq 99 \%)$.

Unfortunately, the particles with $d_{\mathrm{V}}<5 \mu \mathrm{m}$ on a surface of sample are usually difficult to detect and identify by using the present optical system of LA-ICP-MS. Therefore, the synthetic glass sample with $\mathrm{Al}_{2} \mathrm{O}_{3}$ or $\mathrm{MgO}$ particles, whose diameters are smaller than $5 \mu \mathrm{m}$, was not used to obtain the calibration lines for particle size analysis in this study. For the individual ablation of each particle and to obtain the clear isolate peak on an ion intensity chart, the particles on a sample surface were dispersed more than $0.2 \mathrm{~mm}$ apart. Moreover, the particles must be strongly fixed on the sample surface during laser ablation in order to obtain the reliable calibration lines for particle size analysis by LA-ICP-MS.

The samples with pure $\mathrm{Al}_{2} \mathrm{O}_{3}$ and $\mathrm{MgO}$ particles on surface of copper holder and glass were used to obtain the size calibration lines.

\subsection{Analytical procedure}

The laboratory standard glass samples and particles on glass or metal surface are ablated in horizontal direction only along the $\mathrm{X}$ axis. In this case, the laser beam is moved at a constant speed of $0.01 \mathrm{~mm} / \mathrm{s}$ by keeping the focus on sample 
surface. For the generation of a continuous and stable melting of material during ablation, the samples were ablated by using the laser energy of 2.0 to $3.0 \mathrm{~mJ} / \mathrm{shot}$ and frequency of the laser shot of $20 \mathrm{~Hz}$. The length of laser tracks by ablation of each glass standard sample was $1 \mathrm{~mm}$.

In order to obtain a clear relationship between the particle size and ion intensity of isotopes by LA-ICP-MS analysis, the width and depth of laser track must be larger than the ablated particle, as shown in Fig. 1(a). For the ablation of whole particle, the depth and width of laser track can be changed in the ranges of 15 to $105 \mu \mathrm{m}$ and of 10 to $45 \mu \mathrm{m}$, respectively, by the variation of energy and the defocus of laser beam. ${ }^{17)}$ In present investigation, the laser energy was $2.0 \mathrm{~mJ} / \mathrm{shot}$ for the particles with $d_{\mathrm{V}}<20 \mu \mathrm{m}$ and $3.0 \mathrm{~mJ} / \mathrm{shot}$ for that with $d_{\mathrm{V}}=20 \sim 40 \mu \mathrm{m}$. In these cases, the width of laser track after ablation is 25 and $45 \mu \mathrm{m}$, respectively. The length of laser tracks was fixed as 0.5 and $1.0 \mathrm{~mm}$ for particles smaller and larger than $20 \mu \mathrm{m}$, respectively.

Marking of $2 \times 2 \mathrm{~mm}$ squares was made on surface of a sample in order to identify easily the location of particles. Prior to laser ablation, each particle was observed by optical (OM) or scanning electron (SEM) microscopy at a magnification of 1000. The size of particles on photomicrograph was estimated by using an image analyzer as a diameter of circle having the same area as a measured particle (Heywood diameter). Then, the sample was set up into the laser ablation chamber. By using the optical system of LA-ICP-MS, the particles on a sample surface, whose sizes were estimated previously by SEM or OM, are detected and identified. The sample in the chamber is moved horizontally along the $\mathrm{X}$ or $\mathrm{Y}$ axis so that the analyzed particle is placed through the center of the intended laser track, as shown in Fig. 1. The initial point of laser track was positioned at a distance of 150 to $200 \mu \mathrm{m}$ from the particle (Fig. 1(b)). The operating parameters of laser ablation were selected so that the width of laser track was more than the size of this particle. Moreover, only one particle was ablated in each laser track to provide a clear ion intensity peak of isotopes for size calibration line. In the LA-ICP-MS measurement, the size of analyzed particle was estimated as spatial diameter of hypothetical sphere having the same volume as an ablated particle.

\subsection{Chemical analysis}

The total contents of elements in laboratory standard glass samples and those in synthetic materials of $\mathrm{MnO} \cdot \mathrm{SiO}_{2}$ and $2 \mathrm{MnO} \cdot \mathrm{SiO}_{2}$ were analyzed by using the inductively coupled plasma-atomic emission spectrometer (ICP-AES) after fusion of $0.1 \mathrm{~g}$ of sample with $1 \mathrm{~g}$ of ultrapure-grade $\mathrm{Na}_{2} \mathrm{CO}_{3}$, followed by dissolution in the mixture of $10 \mathrm{~cm}^{3}$ of hot $\mathrm{HCl}$ $(1+1)$ and $5 \mathrm{~cm}^{3}$ of $\mathrm{HNO}_{3}(1+1)$.

\section{Results and Discussion}

\subsection{Determination of particle composition}

The chemical compositions of the laboratory standard glass samples with different concentration of added oxides are given in Table 2. The samples (St-0 to St-5), whose matrix glass contains $13 \% \mathrm{NiO}-72 \% \mathrm{~B}_{2} \mathrm{O}_{3}-15 \% \mathrm{Li}_{2} \mathrm{O}$, were used for the analysis of complex particles containing $\mathrm{SiO}_{2}$. The other standard samples (St-6 to St-11), whose matrix
Table 2 Chemical composition of laboratory standard samples.

\begin{tabular}{|c|c|c|c|c|c|c|c|}
\hline \multirow{2}{*}{$\begin{array}{c}\text { Sample } \\
\text { No. }\end{array}$} & \multicolumn{7}{|c|}{ Content of elements/mass $\%$} \\
\hline & Mn & $\mathrm{Si}$ & $\mathrm{Al}$ & $\mathrm{Mg}$ & $\mathrm{Ca}$ & $\mathrm{Ti}$ & $\mathrm{Fe}$ \\
\hline St- $0^{*}$ & 0.001 & 0.010 & 0.003 & $<0.001$ & 0.010 & $<0.001$ & 0.012 \\
\hline St-1* & 0.034 & 0.022 & 0.042 & 0.035 & 0.047 & 0.034 & 0.085 \\
\hline St-2* & 0.072 & 0.065 & 0.086 & 0.069 & 0.086 & 0.065 & 0.161 \\
\hline St- $3^{*}$ & 0.156 & 0.136 & 0.162 & 0.132 & 0.148 & 0.166 & 0.172 \\
\hline St-4* & 0.315 & 0.298 & 0.354 & 0.289 & 0.315 & 0.342 & 0.367 \\
\hline St-5* & 0.441 & - & 0.532 & 0.456 & 0.402 & 0.547 & 0.570 \\
\hline St- $6^{* *}$ & - & - & 0.016 & 0.008 & 0.027 & 0.003 & 0.002 \\
\hline St- $7^{* *}$ & 0.009 & - & 0.025 & 0.010 & 0.031 & 0.011 & 0.022 \\
\hline St- $8^{* *}$ & - & - & 0.024 & 0.022 & 0.031 & 0.028 & 0.016 \\
\hline St-9** & 0.058 & - & 0.096 & 0.051 & 0.081 & 0.043 & 0.067 \\
\hline St $-10^{* *}$ & 0.074 & - & 0.084 & 0.083 & 0.103 & 0.077 & 0.052 \\
\hline St $-11^{* *}$ & 0.101 & - & 0.121 & 0.111 & 0.136 & 0.105 & 0.070 \\
\hline
\end{tabular}

Composition of glass: $* 13 \% \mathrm{NiO}-72 \% \mathrm{~B}_{2} \mathrm{O}_{3}-15 \% \mathrm{Li}_{2} \mathrm{O}, * * 60 \% \mathrm{SiO}_{2}-$ $21 \% \mathrm{~B}_{2} \mathrm{O}_{3}-19 \% \mathrm{Li}_{2} \mathrm{O}$.

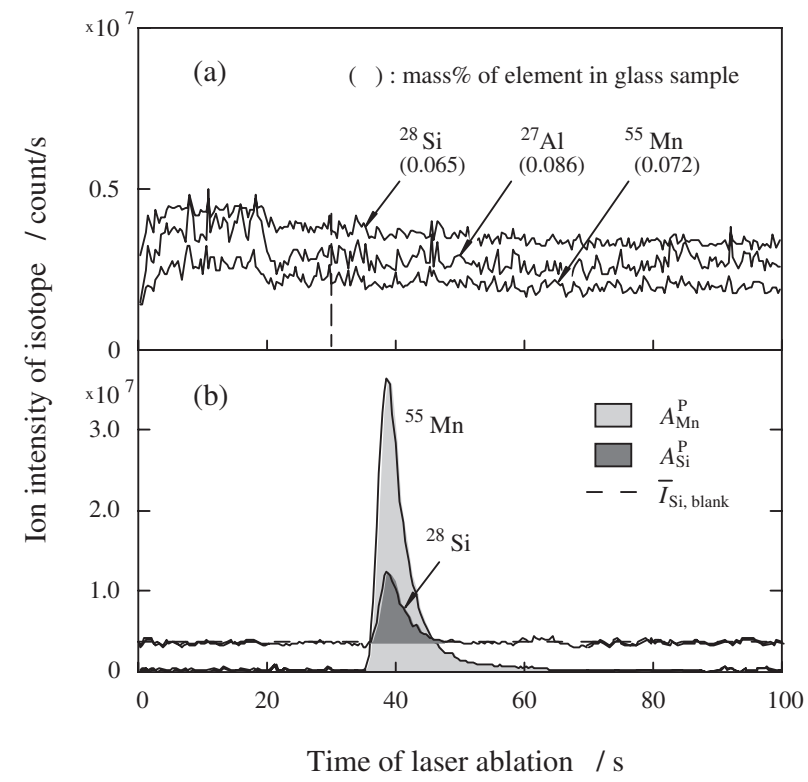

Fig. 2 Ion intensity chart by laser ablation of laboratory standard glass sample (a) and $\mathrm{MnO} \cdot \mathrm{SiO}_{2}$ particle (b).

glass contains $60 \% \mathrm{SiO}_{2}-21 \% \mathrm{~B}_{2} \mathrm{O}_{3}-19 \% \mathrm{Li}_{2} \mathrm{O}$, were used for the analysis of particles not containing $\mathrm{SiO}_{2}$. The homogeneity of the element content in each glass sample was examined previously by LA-ICP-MS. The typical ion intensity chart by laser ablation of sample St-2 is plotted in Fig. 2(a). It is seen that the ion intensity levels of ${ }^{27} \mathrm{Al},{ }^{28} \mathrm{Si}$ and ${ }^{55} \mathrm{Mn}$ isotopes are higher in initial 20 seconds. This is because the melting zone of laser track is not stable in the initial period of ablation. The ion intensity level becomes almost constant after 30 seconds. The finding that the ion intensity peaks, which correspond to the ablated particles, are not present suggests that the analyzed elements in a glass sample are dissolved homogeneously. The same results were obtained for other elements by the examination of each sample. Therefore, it is concluded that the present glass samples can be used as the laboratory standards for the quantitative analysis of the composition of oxide particles. 


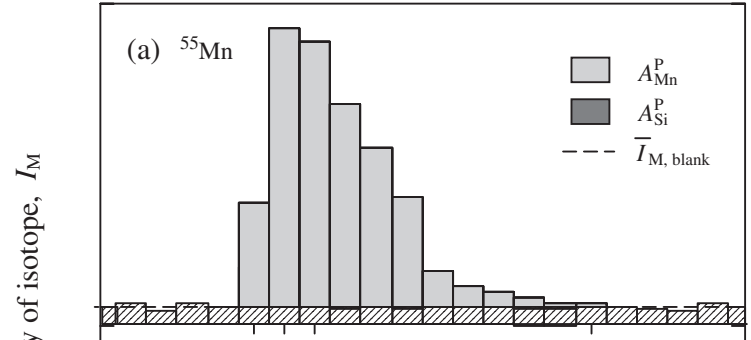

(b) ${ }^{28} \mathrm{Si}$

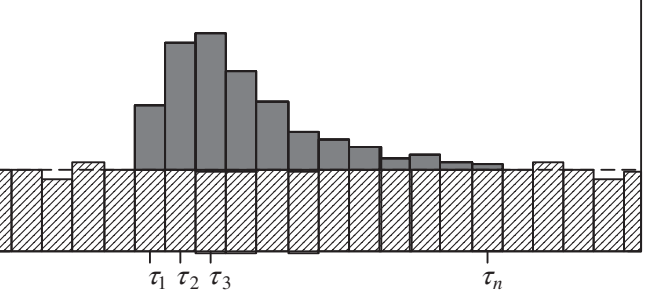

Time of laser ablation

Fig. 3 Schematic diagram of ion intensity peaks by ablation of complex $\mathrm{MnO}-\mathrm{SiO}_{2}$ particle.

More detail is given elsewhere. ${ }^{17)}$ The mean ion intensity for each isotope $\left(\bar{I}_{\mathrm{M}}\right)$ corresponds to total content of element $\mathrm{M}$ in an ablated zone of sample. The $\bar{I}_{\mathrm{M}}$ value is calculated as the average ion intensity in the period of ablation time from 30 to $100 \mathrm{~s}$.

The representative ion intensity chart for ${ }^{28} \mathrm{Si}$ and ${ }^{55} \mathrm{Mn}$ isotopes at the ablation of $\mathrm{MnO} \cdot \mathrm{SiO}_{2}$ particle is shown in Fig. 2(b). A schematic diagram of ion intensity peak obtained by ablation of one complex particle consisting of $\mathrm{MnO}$ and $\mathrm{SiO}_{2}$ is shown in Fig. 3. The gray-colored area of the peak for each element, $A_{\mathrm{M}}^{\mathrm{p}}$, is proportional to the amount of $\mathrm{M}$ element in an ablated particle and calculated as eq. (1).

$$
A_{\mathrm{M}}^{\mathrm{P}}=\sum_{i=1}^{n} I_{\mathrm{M}, i}^{\mathrm{p}}-\bar{I}_{\mathrm{M}, \mathrm{blank}} \cdot n
$$

where $I_{\mathrm{M}, i}^{\mathrm{p}}$ is the ion intensity value of $i$-th segment in a peak for $\mathrm{M}$ isotope, $n$ is the total number of the ion intensity segments in a peak, and $\bar{I}_{\mathrm{M} \text {,blank }}$ is the average ion intensity of $\mathrm{M}$ element for the matrix. The high level of $\bar{I}_{\text {Si,blank }}$ for ${ }^{28} \mathrm{Si}$ isotope in Fig. 2(b) can be explained by the additional effect of $\mathrm{CO}, \mathrm{N}_{2}$ and some other ions which have the same mass number of 28 .

The composition and size of oxide particle can be determined by using the respective calibration lines and $A_{\mathrm{M}}^{\mathrm{p}}$ values for all elements. The detailed description for the calculation of intensity peak area is described elsewhere. ${ }^{17,18)}$

The calibration lines for the analysis of particle composition are obtained by the ablation of samples St- 0 to St-5 using the same parameters. The correlation between mean ion intensity levels of ${ }^{24} \mathrm{Mg},{ }^{27} \mathrm{Al},{ }^{28} \mathrm{Si},{ }^{55} \mathrm{Mn},{ }^{43} \mathrm{Ca},{ }^{47} \mathrm{Ti}$ and ${ }^{57} \mathrm{Fe}$ isotopes and total contents of these elements in glass samples is shown in Fig. 4. It is seen that the mean ion intensity of each isotope increases linearly with increasing the element content. The data points fall reasonably well on the appropriate lines. It can be said from these results that the mean ion intensity signal for $\mathrm{M}$ isotope is in direct proportion to the content of $\mathrm{M}$ element in matrix or oxide particles.

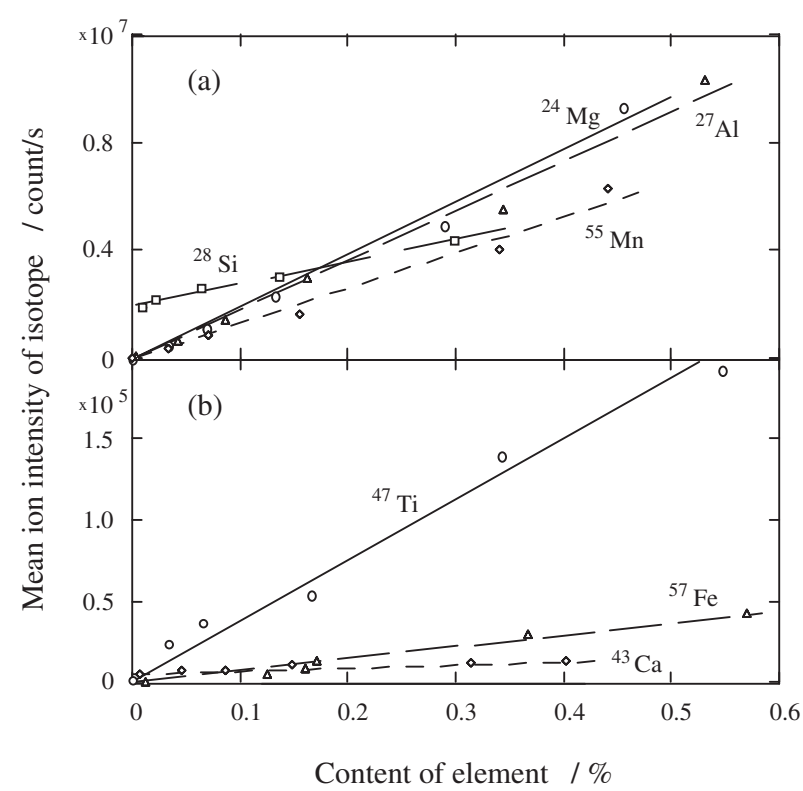

Fig. 4 Correlation between mean ion intensity of isotope and content of elements in laboratory standard glass samples.

The calibration line for $\mathrm{M}$ element, which is obtained by ablation of the laboratory standard glass samples, can be expressed by

$$
\bar{I}_{\mathrm{M}}^{\mathrm{st}}=\alpha_{\mathrm{M}}^{\mathrm{st}}+\beta_{\mathrm{M}}^{\mathrm{st}} \cdot[\% \mathrm{M}]^{\mathrm{st}}
$$

where $\bar{I}_{\mathrm{M}}^{\mathrm{st}}$ and $[\% \mathrm{M}]^{\mathrm{st}}$ are the mean ion intensity of isotope and the total content of $\mathrm{M}$ element in the standard glass sample, respectively, and the values for $\alpha_{\mathrm{M}}^{\mathrm{st}}$ and $\beta_{\mathrm{M}}^{\mathrm{st}}$ are constant for the calibration line of $\mathrm{M}$ element. As shown in Fig. 4, the calibration lines for ${ }^{24} \mathrm{Mg},{ }^{27} \mathrm{Al},{ }^{55} \mathrm{Mn},{ }^{47} \mathrm{Ti}$ and ${ }^{57} \mathrm{Fe}$ start from origin. In this case, the value for $\alpha_{\mathrm{M}}^{\text {st }}$ equals to 0 or has an insignificant value. However, the value for $\alpha_{\mathrm{M}}^{\text {st }}$ for ${ }^{28} \mathrm{Si}$ and ${ }^{43} \mathrm{Ca}$ calibration lines has considerable value due to the additional effect of other isotopes with the same mass number of ion. In this study, the calibration lines for $\mathrm{Si}$ and Mn are obtained as follows:

$$
\begin{aligned}
& \bar{I}_{\mathrm{Si}}^{\mathrm{st}}=1.989 \times 10^{6}+8.154 \times 10^{6}[\% \mathrm{Si}]^{\mathrm{st}} \quad r=0.995 \\
& \bar{I}_{\mathrm{Mn}}^{\mathrm{st}}=0.136 \times 10^{6}+13.85 \times 10^{6}[\% \mathrm{Mn}]^{\mathrm{st}} \quad r=0.996
\end{aligned}
$$

The lines given by eqs. (3) and (4) in which $r$ represents the correlation coefficient were used as the calibration lines for the analysis of $\mathrm{MnO}-\mathrm{SiO}_{2}$ particles. Similar relationships with reasonably large correlation coefficients $(0.925$ to $0.995)$ were obtained for the calibration lines of the others elements.

It should be noted that the relationship between mean ion intensity and total content of element is dependent on the factors such as the condition of LA-ICP-MS system and the operating parameters by ablation. The change of ion intensity signal during long operation time can be eliminated by using the following time correction factor. The corrected ion intensity of isotope for $\mathrm{M}$ element, $I_{\mathrm{M}, t}$, can be estimated by the following equation assuming the linear decrease of ion intensity signal with time:

$$
\begin{aligned}
I_{\mathrm{M}, t}= & I_{\mathrm{M}, t j} \cdot f t_{\mathrm{M}, t j}=I_{\mathrm{M}, t j} \cdot I_{\mathrm{M}, t 1}^{\mathrm{st}} \\
& /\left\{\bar{I}_{\mathrm{M}, t 1}^{\mathrm{st}}-\left(\bar{I}_{\mathrm{M}, t 1}^{\mathrm{st}}-\bar{I}_{\mathrm{M}, t 2}^{\mathrm{st}}\right) \cdot\left(t_{j}-t_{1}\right) /\left(t_{2}-t_{1}\right)\right\}
\end{aligned}
$$


where $I_{\mathrm{M}, t j}$ and $f t_{\mathrm{M}, t j}$ are the ion intensity of isotope in an analyzed sample and the time correction factor, respectively, at a given time $t_{j}$, and $\bar{I}_{\mathrm{M}, t 1}^{\mathrm{st}}$ and $\bar{I}_{\mathrm{M}, t 2}^{\mathrm{st}}$ are the mean ion intensities in a laboratory glass standard at time $t_{1}$ and $t_{2}$, respectively. The analysis of the same laboratory glass standard was repeated at the same operating parameters every 60 minutes for the correction of the sample data.

In order to ablate whole synthetic particle large than $20 \mu \mathrm{m}$, the laser energy was increased to $3.0 \mathrm{~mJ} / \mathrm{shot}$. In this case, the width and depth of laser track were about 45 and $90 \mu \mathrm{m}$, respectively. Since the volume of ablated material (matrix and particle) increases, the ion intensity of analyzed isotope also increases. The data obtained at different laser energy are corrected by using the following parameter correction factor:

$$
I_{\mathrm{M}, p}=I_{\mathrm{M}, p 2} \cdot f p_{\mathrm{M}, p 2}=I_{\mathrm{M}, p 2} \cdot \bar{I}_{\mathrm{M}, p 1}^{\mathrm{st}} / \bar{I}_{\mathrm{M}, p 2}^{\mathrm{st}}
$$

where the values for $I_{\mathrm{M}, p 2}$ and $f p_{\mathrm{M}, p 2}$ are the ion intensity of isotope and the parameter correction factor, respectively, for $\mathrm{M}$ element at a given set of operating parameters $p 2$. The values for $\bar{I}_{\mathrm{M}, p 1}^{\mathrm{st}}$ and $\bar{I}_{\mathrm{M}, p 2}^{\mathrm{st}}$ are the mean ion intensities of isotope in the same laboratory glass standard obtained at different sets of operating parameters $p 1$ and $p 2$, respectively.

The content of each element $\mathrm{M}$ in a homogeneous or heterogeneous multicomponent particle, $[\% \mathrm{M}]^{\mathrm{p}}$, is in direct proportion to the area of ion intensity peak and can be evaluated from eq. (1) and eq. (2) as follows:

$$
[\% \mathrm{M}]^{\mathrm{p}}=A_{\mathrm{M}}^{\mathrm{p}} / \beta_{\mathrm{M}}^{\mathrm{st}}
$$

The content of $\mathrm{M}_{x} \mathrm{O}_{y}$ oxide in a particle can be calculated from $[\% \mathrm{M}]^{\mathrm{P}}$ value by using the molecular weight of $\mathrm{M}_{x} \mathrm{O}_{y}$ and the atomic weight of $\mathrm{M}$ element. The final composition of ablated particle is obtained by recalculating the sum of all oxide components to 100 percentages. More detailed description of calculation of particle composition by LA-ICPMS analysis is given elsewhere. ${ }^{17,18)}$

The final contents of $\mathrm{SiO}_{2}$ and $\mathrm{MnO}$ in synthetic MnO$\mathrm{SiO}_{2}$ particles measured by LA-ICP-MS are compared with those from chemical analysis in Fig. 5(a). The $\mathrm{Al}_{2} \mathrm{O}_{3}$ and $\mathrm{MgO}$ contents in synthetic particles such as $\mathrm{CaO} \cdot 2 \mathrm{Al}_{2} \mathrm{O}_{3}$, $\mathrm{CaO} \cdot \mathrm{Al}_{2} \mathrm{O}_{3}, 12 \mathrm{CaO} \cdot 7 \mathrm{Al}_{2} \mathrm{O}_{3}, 3 \mathrm{CaO} \cdot \mathrm{Al}_{2} \mathrm{O}_{3}, \mathrm{MgO} \cdot \mathrm{Al}_{2} \mathrm{O}_{3}$ and $35 \% \mathrm{CaO}-57 \% \mathrm{Al}_{2} \mathrm{O}_{3}-8 \% \mathrm{MgO}$ on surface of a glass sample are measured by LA-ICP-MS. These values are plotted against those from chemical analysis in Fig. 5(b). The error bar in Figs. 5(a) and 5(b) represents the arithmetic standard deviation of oxide content in several particles of the same synthetic material measured by LA-ICP-MS analysis. It can be seen in Fig. 5 that the concentrations of oxides in particles determined by LA-ICP-MS agree reasonably well with those by the chemical analysis. However, it should be pointed out that the arithmetic standard deviation for $\mathrm{MnO} \cdot \mathrm{SiO}_{2}$ particles $( \pm 8 \%)$ is not so small as for most other synthetic materials. This can be explained by the slight heterogeneity of composition among the synthetic $\mathrm{MnO} \cdot \mathrm{SiO}_{2}$ particles.

\subsection{Determination of particle size}

The size of one component oxide particle $\left(\mathrm{M}_{x} \mathrm{O}_{y}\right)$ can be estimated from the area of the ion intensity peak for $\mathrm{M}$ element, $A_{\mathrm{M}}^{\mathrm{p}}$, in ablated particle (see Fig. 2(b)) by using a size calibration line for $\mathrm{M}$ element. This calibration line is

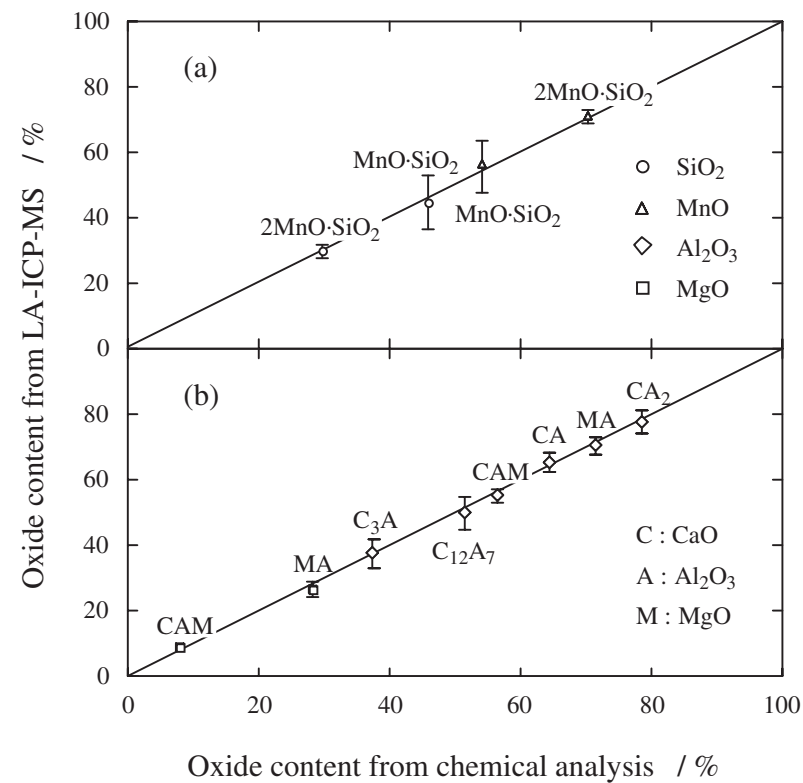

Fig. 5 Comparison of oxide content in synthetic particles obtained from LA-ICP-MS with that from chemical analysis. (a) $\mathrm{MnO}_{-} \mathrm{SiO}_{2}$ and (b) $\mathrm{CaO}-$ $\mathrm{Al}_{2} \mathrm{O}_{3}, \mathrm{CaO}-\mathrm{Al}_{2} \mathrm{O}_{3}-\mathrm{MgO}$ and $\mathrm{MgO} \cdot \mathrm{Al}_{2} \mathrm{O}_{3}$ particles.

obtained by the individual ablation of more than $10 \mathrm{M}_{x} \mathrm{O}_{y}$ particles with known size. It was found in a previous study ${ }^{18)}$ that $A_{\mathrm{M}}^{\mathrm{p}}$ value is proportional to the amount of this element in an ablated oxide particle, $m_{\mathrm{M}}^{\mathrm{p}}$, and expressed as eq. (8).

$$
A_{\mathrm{M}}^{\mathrm{p}}=k_{\mathrm{M}}^{\mathrm{st}} \cdot m_{\mathrm{M}}^{\mathrm{p}}
$$

where $k_{\mathrm{M}}^{\text {st }}$ is a constant estimated from the slope of size calibration line for $\mathrm{M}$ element.

By assuming that an ablated particle is spherical, the mass of one component in $\mathrm{M}_{x} \mathrm{O}_{y}$ particle, $m_{\mathrm{M}_{x} \mathrm{O}_{y}}^{\mathrm{p}}$, can be estimated as follows:

$$
m_{\mathrm{M}_{x} \mathrm{O}_{y}}^{\mathrm{p}}=v_{\mathrm{M}_{x} \mathrm{O}_{y}}^{\mathrm{p}} \cdot \rho_{\mathrm{M}_{x} \mathrm{O}_{y}}=\pi / 6 \cdot d_{\mathrm{V}, \mathrm{M}_{x} \mathrm{O}_{y}}^{3} \cdot \rho_{\mathrm{M}_{x} \mathrm{O}_{y}}
$$

where $v_{\mathrm{M}_{x} \mathrm{O}_{y}}^{\mathrm{p}}, \rho_{\mathrm{M}_{x} \mathrm{O}_{y}}$ and $d_{\mathrm{V}, \mathrm{M}_{x} \mathrm{O}_{y}}$ are the volume, density and spatial diameter of a $\mathrm{M}_{x} \mathrm{O}_{y}$ particle, respectively. Moreover, the $m_{\mathrm{M}_{x} \mathrm{O}_{y}}^{\mathrm{p}}$ value of an analyzed particle can be expressed by eq. (10).

$$
\begin{aligned}
m_{\mathrm{M}_{x} \mathrm{O}_{y}}^{\mathrm{p}} & =m_{\mathrm{M}}^{\mathrm{p}} \cdot \mathrm{MW}_{\mathrm{M}_{x} \mathrm{O}_{y}} /\left(x \cdot \mathrm{AW}_{\mathrm{M}}\right) \\
& =A_{\mathrm{M}}^{\mathrm{p}} / k_{\mathrm{M}}^{\mathrm{st}} \cdot \mathrm{MW}_{\mathrm{M}_{x} \mathrm{O}_{y}} /\left(x \cdot \mathrm{AW}_{\mathrm{M}}\right)
\end{aligned}
$$

where $\mathrm{MW}_{\mathrm{M}_{x} \mathrm{O}_{y}}$ and $\mathrm{AW}_{\mathrm{M}}$ are the molecular mass of $\mathrm{M}_{x} \mathrm{O}_{y}$ and the atomic mass of $\mathrm{M}$ element, respectively. $x$ is the number of atoms of $\mathrm{M}$ element in $\mathrm{M}_{x} \mathrm{O}_{y}$ molecule.

The relationship between the $A_{\mathrm{M}}^{\mathrm{p}}$ value and size of one component oxide particle can be evaluated from eqs. (9) and (10) as follows:

$$
\begin{aligned}
A_{\mathrm{M}}^{\mathrm{p}} & =\left(\pi / 6 \cdot x \cdot \mathrm{AW}_{\mathrm{M}} \cdot k_{\mathrm{M}}^{\mathrm{st}} \cdot \rho_{\mathrm{M}_{x} \mathrm{O}_{y}} / \mathrm{MW}_{\mathrm{M}_{x} \mathrm{O}_{y}}\right) \cdot d_{\mathrm{V}, \mathrm{M}_{x} \mathrm{O}_{y}}^{3} \\
& =c_{\mathrm{M}} \cdot d_{\mathrm{V}, \mathrm{M}_{x} \mathrm{O}_{y}}^{3}
\end{aligned}
$$

where $c_{\mathrm{M}}$ is a constant which can be estimated from the slope of size calibration line for $\mathrm{M}$ element.

The correlation between the $A_{\mathrm{M}}^{\mathrm{p}}$ and $d_{\mathrm{V}, \mathrm{M}_{x} \mathrm{O}_{y}}$ values for the ${ }^{28} \mathrm{Si}$ and ${ }^{55} \mathrm{Mn}$ isotopes in $\mathrm{MnO} \cdot \mathrm{SiO}_{2}$ and $2 \mathrm{MnO} \cdot \mathrm{SiO}_{2}$ particles and for ${ }^{27} \mathrm{Al}$ isotope in $\mathrm{Al}_{2} \mathrm{O}_{3}, 12 \mathrm{CaO} \cdot 7 \mathrm{Al}_{2} \mathrm{O}_{3}$ and $35 \% \mathrm{CaO}-57 \% \mathrm{Al}_{2} \mathrm{O}_{3}-8 \% \mathrm{MgO}$ particles are shown in Fig. 6. The obtained relationships for $\mathrm{Si}, \mathrm{Mn}$ and $\mathrm{Al}$ are expressed by 


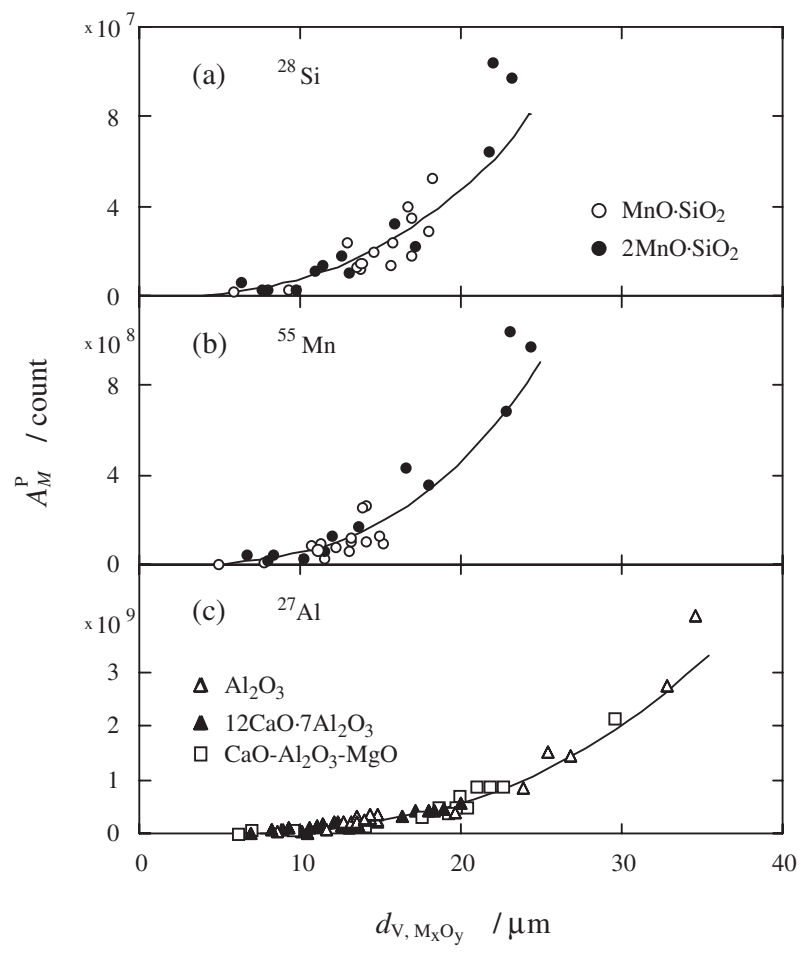

Fig. 6 Correlation between area of ion intensity peak and size of $\mathrm{SiO}_{2}$, $\mathrm{MnO}$ and $\mathrm{Al}_{2} \mathrm{O}_{3}$ particles.

$$
\begin{aligned}
& A_{\mathrm{Si}}^{\mathrm{p}}=20470\left(d_{\mathrm{V}, \mathrm{SiO}_{2}}\right)^{2.58} \quad r=0.927 \\
& A_{\mathrm{Mn}}^{\mathrm{p}}=56840\left(d_{\mathrm{V}, \mathrm{MnO}}\right)^{2.99} \quad r=0.965 \\
& A_{\mathrm{Al}}^{\mathrm{p}}=66620\left(d_{\mathrm{V}, \mathrm{Al}_{2} \mathrm{O}_{3}}\right)^{3.04} \quad r=0.985
\end{aligned}
$$

The relationship for $\mathrm{Al}$ expressed by eq. (14) was obtained with consideration for results of previous reports ${ }^{18,19)}$ and new data of present study. Some scattering of the data points from the lines in Fig. 6 is due to the error arising from the estimation of size for irregular particles from the equivalentarea diameter. The correlation between the $A_{\mathrm{Mg}}^{\mathrm{p}}$ and $d_{\mathrm{V}, \mathrm{MgO}}$ values for the ${ }^{24} \mathrm{Mg}$ isotope by LA-ICP-MS analysis of pure $\mathrm{MgO}$ particles are obtained in previous study ${ }^{18)}$ and can be written in similar form

$$
A_{\mathrm{Mg}}^{\mathrm{p}}=67040\left(d_{\mathrm{V}, \mathrm{MgO}}\right)^{3.04} \quad r=0.972
$$

It can be seen that the correlation between the $A_{\mathrm{M}}^{\mathrm{p}}$ and $d_{\mathrm{V}, \mathrm{M}_{x} \mathrm{O}_{y}}$ values obtained experimentally with reasonably large correlation coefficients ( 0.927 to 0.985$)$ and expressed by eqs. (12) to (15) have a similar shape with eq. (11). These relationships for $\mathrm{Si}, \mathrm{Mn}, \mathrm{Al}$ and $\mathrm{Mg}$ were used in present study as calibration lines for the size determination of oxide particles containing $\mathrm{SiO}_{2}, \mathrm{MnO}, \mathrm{Al}_{2} \mathrm{O}_{3}$ and $\mathrm{MgO}$.

The total mass of a homogeneous multicomponent oxide particle, $m_{\mathrm{V}, \text { hom }}^{\mathrm{p}}$, such as $\mathrm{MnO} \cdot \mathrm{SiO}_{2}$ or $2 \mathrm{MnO} \cdot \mathrm{SiO}_{2}$, can be calculated by using the values of mass, $m_{\mathrm{M}_{x} \mathrm{O}_{y}}^{\mathrm{p}}$, and concentration, $\left[\% \mathrm{M}_{x} \mathrm{O}_{y}\right]^{\mathrm{P}}$, for one oxide component of this particle

$$
m_{\mathrm{V}, \mathrm{hom}}^{\mathrm{p}}=m_{\mathrm{M}_{x} \mathrm{O}_{y}}^{\mathrm{p}} /\left[\% \mathrm{M}_{x} \mathrm{O}_{y}\right]^{\mathrm{P}} \times 100 \%
$$

In this case, the diameter of this particle in $3-\mathrm{D}, d_{\mathrm{V}, \mathrm{hom}}$, can be evaluated from eqs. (10), (11) and (16) as follows:

$$
\begin{aligned}
d_{\mathrm{V}, \text { hom }} & =\left(6 / \pi \cdot m_{\mathrm{V}, \text { hom }}^{\mathrm{p}} / \rho_{\text {hom }}\right)^{1 / 3} \\
& =\left(100 /\left[\% \mathrm{M}_{x} \mathrm{O}_{y}\right]^{\mathrm{P}} \cdot \rho_{\mathrm{M}_{x} \mathrm{O}_{y}} / \rho_{\mathrm{hom}} \cdot A_{\mathrm{M}}^{\mathrm{p}} / c_{\mathrm{M}}\right)^{1 / 3}
\end{aligned}
$$

where $\rho_{\text {hom }}$ is the density of a homogeneous particle $\left(=3.77 \times 10^{-3} \mathrm{~g} / \mathrm{mm}^{3}\right.$ for $\mathrm{MnO} \cdot \mathrm{SiO}_{2}$ and $4.12 \times 10^{-3}$ $\mathrm{g} / \mathrm{mm}^{3}$ for $2 \mathrm{MnO} \cdot \mathrm{SiO}_{2}$ ). In accordance with eq. (17), the sizes of any homogeneous complex oxide particles with known density, $\rho_{\text {hom }}$, can be estimated from LA-ICP-MA analysis by using values of $\left[\% \mathrm{M}_{x} \mathrm{O}_{y}\right]^{\mathrm{P}}, A_{\mathrm{M}}^{\mathrm{P}}$ and $c_{\mathrm{M}}$, which can be obtained from composition and size calibration lines for one of oxide component in this particle.

In the case of LA-ICP-MS analysis for a heterogeneous multiphase particle or homogeneous complex particle with unknown density such as $\mathrm{CaO}-\mathrm{Al}_{2} \mathrm{O}_{3}-\mathrm{MgO}$, it is assumed that total volume of particle, $V_{\text {het }}^{\mathrm{P}}$, is equal to the sum of volumes for all oxide components $\left(V_{\text {het }}^{\mathrm{P}}=V_{\mathrm{CaO}}^{\mathrm{P}}+V_{\mathrm{Al}_{2} \mathrm{O}_{3}}^{\mathrm{P}}+\right.$ $\left.V_{\mathrm{MgO}}^{\mathrm{P}}\right)$. The size of this particle, $d_{\mathrm{V} \text {,het }}$, is estimated by eq. (18).

$$
\begin{aligned}
d_{\mathrm{V}, \text { het }}= & \left(6 / \pi \cdot V_{\text {het }}^{\mathrm{p}}\right)^{1 / 3}=\left\{6 / \pi\left(m_{\mathrm{CaO}}^{\mathrm{p}} / \rho_{\mathrm{CaO}}\right.\right. \\
& \left.\left.+m_{\mathrm{Al}_{2} \mathrm{O}_{3}}^{\mathrm{p}} / \rho_{\mathrm{Al}_{2} \mathrm{O}_{3}}+m_{\mathrm{MgO}}^{\mathrm{p}} / \rho_{\mathrm{MgO}}\right)\right\}^{1 / 3}
\end{aligned}
$$

where $m_{\mathrm{CaO}}^{\mathrm{p}}, m_{\mathrm{Al}_{2} \mathrm{O}_{3}}^{\mathrm{p}}$ and $m_{\mathrm{MgO}}^{\mathrm{p}}$ are the mass of $\mathrm{CaO}, \mathrm{Al}_{2} \mathrm{O}_{3}$ and $\mathrm{MgO}$ oxides in an ablated heterogeneous particle, respectively, and $\rho_{\mathrm{CaO}}, \rho_{\mathrm{Al}_{2} \mathrm{O}_{3}}$ and $\rho_{\mathrm{MgO}}$ are the density of $\mathrm{CaO} \quad\left(=3.37 \times 10^{-3} \mathrm{~g} / \mathrm{mm}^{3}\right), \quad \mathrm{Al}_{2} \mathrm{O}_{3} \quad\left(=3.97 \times 10^{-3} \mathrm{~g} /\right.$ $\left.\mathrm{mm}^{3}\right)$ and $\mathrm{MgO}\left(=3.65 \times 10^{-3} \mathrm{~g} / \mathrm{mm}^{3}\right)$, respectively. The comparison of results obtained from eq. (17) and eq. (18) for complex particles such as $12 \mathrm{CaO} \cdot 7 \mathrm{Al}_{2} \mathrm{O}_{3}, \mathrm{CaO} \cdot 2 \mathrm{Al}_{2} \mathrm{O}_{3}$, $3 \mathrm{CaO} \cdot \mathrm{MgO} \cdot 2 \mathrm{Al}_{2} \mathrm{O}_{3}, \mathrm{MgO} \cdot \mathrm{SiO}_{2}, \mathrm{MnO} \cdot \mathrm{SiO}_{2}, 2 \mathrm{MnO} \cdot \mathrm{SiO}_{2}$ and some others, whose densities are known, showed that the difference between the $d_{\mathrm{V}}$ values calculated from these equations is not greater than $10 \%$. Therefore, eq. (18) can be used with sufficient accuracy for estimation of size not only for heterogeneous multiphase particles, but also for homogeneous complex particles with unknown density.

When the particle composition is already determined by using appropriate calibration lines, the $m_{\mathrm{CaO}}^{\mathrm{p}}$ and $m_{\mathrm{MgO}}^{\mathrm{p}}$ values can be expressed by using $m_{\mathrm{Al}_{2} \mathrm{O}_{3}}^{\mathrm{p}}$ value as follows:

$$
\begin{aligned}
m_{\mathrm{CaO}}^{\mathrm{p}} & =[\% \mathrm{CaO}]^{\mathrm{p}} /\left[\% \mathrm{Al}_{2} \mathrm{O}_{3}\right]^{\mathrm{p}} \cdot m_{\mathrm{Al}_{2} \mathrm{O}_{3}}^{\mathrm{p}} \\
m_{\mathrm{MgO}}^{\mathrm{p}} & =[\% \mathrm{MgO}]^{\mathrm{p}} /\left[\% \mathrm{Al}_{2} \mathrm{O}_{3}\right]^{\mathrm{p}} \cdot m_{\mathrm{Al}_{2} \mathrm{O}_{3}}^{\mathrm{p}}
\end{aligned}
$$

where $[\% \mathrm{CaO}]^{\mathrm{P}},\left[\% \mathrm{Al}_{2} \mathrm{O}_{3}\right]^{\mathrm{P}}$ and $[\% \mathrm{MgO}]^{\mathrm{P}}$ are the content of $\mathrm{CaO}, \mathrm{Al}_{2} \mathrm{O}_{3}$ and $\mathrm{MgO}$ oxides in the analyzed particle, respectively.

By substituting eqs. (10), (11), (19) and (20) into eq. (18), the size of heterogeneous particle, $d_{\mathrm{V} \text {,het }}$, can be written as follows:

$$
\begin{aligned}
d_{\mathrm{V}, \text { het }}= & \left(A_{\mathrm{Ca}}^{\mathrm{p}} / c_{\mathrm{Ca}}+A_{\mathrm{Al}}^{\mathrm{p}} / c_{\mathrm{Al}}+A_{\mathrm{Mg}}^{\mathrm{p}} / c_{\mathrm{Mg}}\right)^{1 / 3} \\
= & \left\{\left([\% \mathrm{CaO}]^{\mathrm{P}} /\left[\% \mathrm{Al}_{2} \mathrm{O}_{3}\right]^{\mathrm{P}} \cdot \rho_{\mathrm{Al}_{2} \mathrm{O}_{3}} / \rho_{\mathrm{CaO}}+1\right.\right. \\
& \left.+[\% \mathrm{MgO}]^{\mathrm{P}} /\left[\% \mathrm{Al}_{2} \mathrm{O}_{3}\right]^{\mathrm{P}} \cdot \rho_{\mathrm{Al}_{2} \mathrm{O}_{3}} / \rho_{\mathrm{MgO}}\right) \\
& \left.\cdot A_{\mathrm{Al}}^{\mathrm{p}} / c_{\mathrm{Al}}\right\}^{1 / 3}
\end{aligned}
$$

In accordance with eq. (21), the size of any heterogeneous multiphase particles or homogeneous complex particles with unknown density can be estimated from LA-ICP-MA analysis by using the content of all oxides in ablated particle and $A_{\mathrm{M}}^{\mathrm{P}}$ and $c_{\mathrm{M}}$ values which can be obtained from size calibration lines for one of oxide component of this particle.

The comparison of particle size determined by LA-ICPMS with that by SEM observation is shown in Fig. 7. In Fig. $7(\mathrm{a})$, the diameters, $d_{\mathrm{V}}$, of $\mathrm{MnO} \cdot \mathrm{SiO}_{2}$ and $2 \mathrm{MnO} \cdot \mathrm{SiO}_{2}$ particles are calculated by using the calibration lines for $\mathrm{Si}$ 
Table 3 Deviation of particle size measured by LA-ICP-MS from that by SEM.

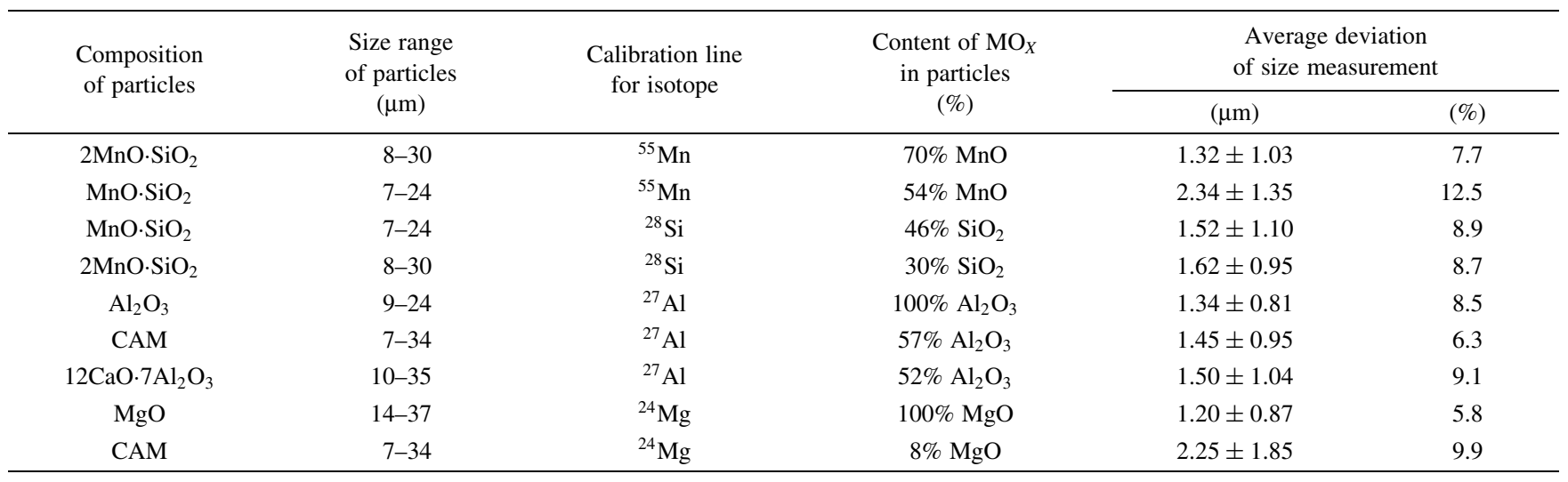

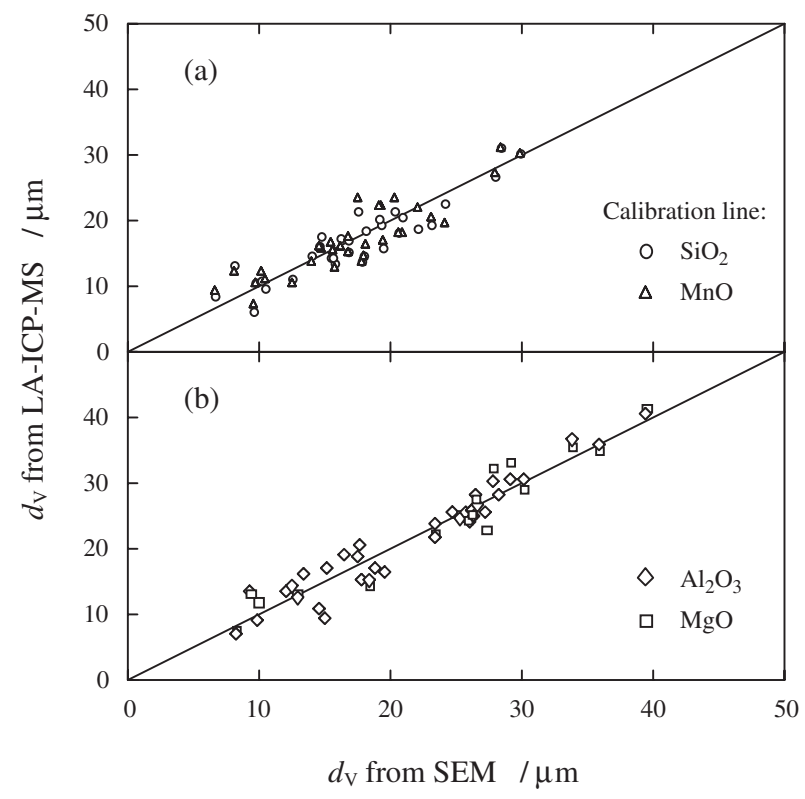

Fig. 7 Comparison of particle size obtained by LA-ICP-MS and that by SEM. (a) $\mathrm{MnO}-\mathrm{SiO}_{2}$ and (b) $\mathrm{CaO}-\mathrm{Al}_{2} \mathrm{O}_{3}, \mathrm{CaO}-\mathrm{Al}_{2} \mathrm{O}_{3}-\mathrm{MgO}$ and $\mathrm{MgO} \cdot \mathrm{Al}_{2} \mathrm{O}_{3}$ particles.

and $\mathrm{Mn}$ which are expressed by eq. (12) and eq. (13), respectively. The $d_{\mathrm{V}}$ values for the $\mathrm{CaO}-\mathrm{Al}_{2} \mathrm{O}_{3}, 35 \% \mathrm{CaO}$ $57 \% \mathrm{Al}_{2} \mathrm{O}_{3}-8 \% \mathrm{MgO}$ and $\mathrm{MgO} \cdot \mathrm{Al}_{2} \mathrm{O}_{3}$ particles shown in Fig. 7(b) are estimated by using the calibration lines for $\mathrm{Al}$ and $\mathrm{Mg}$ which are expressed by eq. (14) and eq. (15), respectively. It is clear from Fig. 7 that the diameter of particles determined by LA-ICP-MS agrees reasonably well with that obtained by SEM.

The average deviation of particle size measurement by using LA-ICP-MS and that by SEM $\left(\Delta d_{\mathrm{V}}=d_{\mathrm{V}(\mathrm{SEM})}-\right.$ $\left.d_{\mathrm{V}(\text { LA-ICP-MS) }}\right)$ is given in Table 3 for different pure and complex oxide particles consisting of $\mathrm{SiO}_{2}, \mathrm{MnO}, \mathrm{Al}_{2} \mathrm{O}_{3}$ and $\mathrm{MgO}$. The spatial diameters, $d_{\mathrm{V}}$, of analyzed particles are in the range of 7 to $37 \mu \mathrm{m}$. It can be seen that the difference between the $d_{\mathrm{V}}$ values obtained by LA-ICP-MS using the size calibration lines for $\mathrm{Si}$ and $\mathrm{Mn}$ and those by SEM is on average 1.3 to $1.6 \mu \mathrm{m}(8-9 \%)$ for $2 \mathrm{MnO} \cdot \mathrm{SiO}_{2}$ and 1.5 to $2.3 \mu \mathrm{m}(9-13 \%)$ for $\mathrm{MnO} \cdot \mathrm{SiO}_{2}$ particles. The significant $\Delta d_{\mathrm{V}}$ values obtained in the size estimation of $\mathrm{MnO} \cdot \mathrm{SiO}_{2}$ particles with non-congruent melting can be explained by the nonuni- form composition due to the precipitation of $\mathrm{SiO}_{2}, \mathrm{MnO} \cdot \mathrm{SiO}_{2}$ and $2 \mathrm{MnO} \cdot \mathrm{SiO}_{2}$ phases during cooling. The difference between the $d_{\mathrm{V}}$ values obtained by LA-ICP-MS using the size calibration lines for $\mathrm{Al}$ and $\mathrm{Mg}$ and those by SEM is on average 1.3 to $1.5 \mu \mathrm{m}(8-9 \%)$ and 1.2 to $2.3 \mu \mathrm{m}$ (6-10\%), respectively. The significant error caused by using the $\mathrm{Mg}$ calibration line for LA-ICP-MS analysis of $\mathrm{CaO}-\mathrm{Al}_{2} \mathrm{O}_{3}-\mathrm{MgO}$ particles is supposed to be due to the small content of $\mathrm{MgO}$ (only 8\%) in this synthetic material.

It follows from the results given in Table 3 that the $\Delta d_{\mathrm{V}}$ value for LA-ICP-MS measurement of particle size increases with decreasing the content of $\mathrm{M}_{x} \mathrm{O}_{y}$ oxide in ablated particle by using the size calibration lines for $\mathrm{M}$ isotope. Therefore, when $\mathrm{M}_{x} \mathrm{O}_{y}$ is dominant in this particle, the calibration line of major element $\mathrm{M}$ should be chosen for the size determination by LA-ICP-MS.

The quantitative analyses of particle size and composition by LA-ICP-MS are carried out based on the difference between concentrations of elements in matrix or background material and that in particles. It is considered that this difference in the case of steel and alloys deoxidized with $\mathrm{Si}$, $\mathrm{Mn}, \mathrm{Al}, \mathrm{Mg}, \mathrm{Ca}$ and others deoxidants is suggested to be the range from 10 to 1000 times or more. In this case, the ion intensity peaks of particles obtained by LA-ICP-MS analysis are distinct clear from background level which corresponds to the content of matrix metal. Therefore, the application of LA-ICP-MS in steelmaking industry is one of perspective direction for simultaneous quantitative analysis of the composition and size of inclusion particles in metals. The results, some problems and limitation of LA-ICP-MS method by analysis of particles in real alloys and steels would be discussed in a separate paper.

\section{Conclusions}

A new analytical approach by using LA-ICP-MS has been developed for the simultaneous quantitative determination of composition and three-dimensional size of oxide particles consisting of $\mathrm{SiO}_{2}, \mathrm{MnO}, \mathrm{Al}_{2} \mathrm{O}_{3}, \mathrm{MgO}$ and $\mathrm{CaO}$. The method for the preparation of laboratory glass standard samples has been improved. The procedure for the preparation of samples with the synthetic particles fixed on a surface of glass or copper plate was also developed. These samples are used to obtain the calibration lines for analysis 
of particle composition and size. It was found that the area of ion intensity peak for each element is linearly proportional to the amount of this element in an ablated particle. The composition and size of multicomponent oxide particles could be determined by using LA-ICP-MS technique and the obtained calibration lines for $\mathrm{Si}, \mathrm{Mn}, \mathrm{Al}$ and $\mathrm{Mg}$. The composition and size of one component and complex synthetic particles measured by LA-ICP-MS are in good agreement with those by chemical analysis and by SEM observation. The difference between the size of multicomponent oxide particles determined by LA-ICP-MS and that by SEM is from 6 to $13 \%$ on average in the range of $d_{\mathrm{V}}=7 \sim 40 \mu \mathrm{m}$. It was confirmed that LA-ICP-MS method has the perspective to be applied for the quick and simultaneous measurement of composition and size of particles on surface of metal and other materials.

\section{REFERENCES}

1) P. Arrowsmith: Anal. Chem. 59 (1987) 1437-1444.

2) T. Mochizuki, A. Sakashita, H. Iwata, T. Tagaya, T. Shimamura and P. Blair: Anal. Sci. 4 (1988) 403-409.

3) T. Mochizuki, A. Sakashita, T. Tsuji, H. Iwata, Y. Ishibashi and N. Gunji: Anal. Sci. 7 (1991) 1851-1858.

4) T. Akiyoshi, A. Sakashita, T. Maekawa, Y. Ishibashi, S. Kinoshiro and
T. Mochizuki: Tetsu-to-Hagane 83 (1997) 42-47.

5) Y. Ishibashi: ISIJ International 37 (1997) 885-891.

6) D. Günther, A. Audetat, R. Frischknecht and C. A. Heinrich: J. Anal. At. Spectrom. 13 (1998) 263-270.

7) D. Günther, S. E. Jackson and H. P. Longerich: Spectrochim. Acta 54B (1999) 381-409.

8) B. Schafer, R. Frischknecht, D. Gunther and D. B. Dingwell: Eur. J. Mineral 11 (1999) 415-426.

9) J. S. Becker and H. J. Dietze, Fresenius: J. Anal. Chem. 365 (1999) 429-434.

10) F. Vanhaecke and L. Moens Fresenius: J. Anal. Chem. 364 (1999) 440451.

11) Y. Ishibashi: BUNSEKI KAGAKU 48 (1999) 463-464.

12) B. Muller, R. Frischknecht, T. M. Seward, C. A. Heinrich and W. C. Gallegos: Mineralium Deposita 36 (2001) 680-688.

13) W. E. Halter, T. Pettke, C. A. Heinrich and B. Rothen-Rutishauser: Chem. Geol. 183 (2002) 63-86.

14) Y. Ishibashi: ISIJ Int. 42 (2002) Supplement S137-S139.

15) C. A. Heinrich, T. Pettke, W. E. Halter, M. Aigner-Torres, A. Audetat, D. Günther, B. Hattendorf, D. Bleiner, M. Guillong and I. Horn: Geochim. Cosmochim. Acta 67 (2003) 3473-3497.

16) W. E. Halter, T. Pettke and C. A. Heinrich: Contrib. Mineral. Petrol. 147 (2004) 385-396.

17) A. V. Karasev, R. Inoue and H. Suito: ISIJ Int. 41 (2001) 757-765.

18) A. V. Karasev and H. Suito: ISIJ Int. 44 (2004) 356-363.

19) A. V. Karasev and H. Suito: ISIJ Int. 44 (2004) 364-371.

20) T. Mochizuki, A. Sakashita, H. Iwata, Y. Ishibashi and N. Gunji: BUNSEKI KAGAKU 41 (1992) 49-55.

21) T. Matsumura and A. Yamamoto: CAMP-ISIJ 9 (1996) 784. 